American Journal of Biochemistry and Biotechnology 5 (2): 63-74, 2009

ISSN 1553-3468

(C) 2009 Science Publications

\title{
Transgenic Indian Cotton (Gossypium hirsutum) Harboring Rice Chitinase Gene (Chi II) Confers Resistance to Two Fungal Pathogens
}

\author{
${ }^{1,2}$ M. Ganesan, ${ }^{2,3}$ P. Bhanumathi, ${ }^{2}$ K. Ganesh Kumari, ${ }^{2}$ A. Lakshmi Prabha \\ ${ }^{1,2}$ Pill-Soon Song and ${ }^{2} \mathrm{~N}$. Jayabalan \\ ${ }^{1}$ Faculty of Biotechnology, Cheju National University, 66 Jeju Daehak-Ro, Jeju 690-756, \\ Environmental Biotechnology National Core Research Centre, Gyeonsang National University, \\ Jinju 660-701, Republic of Korea \\ ${ }^{2}$ Plant Biotechnology Unit, Department of Plant Science, Bharathidasan University, \\ Tiruchirappalli 620 024, Tamil Nadu, India \\ ${ }^{3}$ Department of Botany, Periyar EVR College, Tiruchirappalli 620 023, Tamil Nadu, India
}

\begin{abstract}
Problem statement: The present investigation described a simple and reproducible protocol for transgenic cotton regeneration and characterization of chitinase (Chi II) gene expression against two different fungal pathogens in cotton. Approach: Transgenic cotton (Gossypium hirsutum cv. SVPR2) plants were produced by pCambia-bar-Chi II $(13.8 \mathrm{~kb})$ under the control of the CaMV $35 \mathrm{~S}$ promoter, harbored in the strain LBA 4404 Agrobacterium tumefaciens by using shoot tip explants. Results: Finally, from the 10 experiments, $21.8 \%$ of transformation frequency was recorded. Segregation ratio of 3:1 was recorded in the $\mathrm{T}_{0}$ plant seeds. Polymerase chain reaction and southern blotting analysis were used to confirm the integration of Chi II transgene in the $\mathrm{T}_{0}$ plants genome of putative transgenics. Quantitiave and qualitative (SDS-PAGE) analyses were also carried out to confirm the expression of chitinase enzyme in $\mathrm{T}_{0}$ plants. Further, randomly selected transgenic plants $\left(\mathrm{T}_{0}\right)$ were analyzed for disease tolerance by evaluating them with spores of Fusarium oxysporum and Alternaria macrospora. All the selected PCR positive plants showed enhanced disease resistance against Fusarium wilt. The plants selected randomly showed an enhanced survival rate compared with the control when they were grown in earthen pots inoculated with $1 \times 10^{5}$ spores $100^{-1} \mathrm{~g}$ of soil mixture. Another four randomly selected plantlets were sprayed with spores of Alternaria macrospora in order to test their tolerance to Alternaria leaf spot disease. After 20 days of culture, the number of lesions per leaf and the lesion length per leaf spot in non-transferred leaves increased. In the case of transgenic plantlets, lesion formation was completely absent. Conclusion: The disease resistance against Fusarium wilt and Alternaria leaf spot in cotton strains would serve as good breeding materials for producing fungal disease resistant cotton varieties.
\end{abstract}

Key words: Cotton, transformation, shoots tip culture, phosphinothricin, chitinase gene, Fusarium wilt, alternaria leaf spot, disease resistance

\section{INTRODUCTION}

Cotton (Gossypium hirsutum L.) has been estimated that 180 million people depend on cotton fiber production. Apart from the fiber production, cotton cultivation was also used for the production of gossypol due to its wide range of biological properties including anti-cancer, antimicrobial, anti-HIV, antioxidative and male contraceptive activities ${ }^{[1]}$. Among the cotton producing countries, India ranks first in cultivation, with 32 of the world's total area followed by USA (23) and China $(20 \%)^{[2]}$. Unfortunately, in the production rate, India ranks third. This is due to the non-availability of genetically modified superior genotypes with desired traits. In Indian varieties, the yield of cotton was significantly affected by several biotic and abiotic factors, particularly by insect pests and fungal pathogens. However, the chemical control of pests and diseases has not always been effective, resulting in crop failure or heavy reduction in yield. In the cotton market, before 1996, a $29 \%$ loss in the total income was accounted for by these insect pests and

Corresponding Author: M. Ganesan, Faculty of Biotechnology, Cheju National University, 66 Jeju Daehak-Ro, Jeju 690-756, Jinju 660-701, Republic of Korea Tel: 82-(0)10-7110-9790/82-(0)64-754-3395 Fax: 82-(0)64-726-3395 
Am. J. Biochem. \& Biotech., 5 (2): 63-74, 2009

diseases per year. After the introduction of Bt cotton, the yield loss caused by insect pests was significantly controlled ${ }^{[3]}$. In India also Bt cotton is being field tested for insect pest control.

Apart from the insect pests, the fungal pathogens cause an $8-12 \%$ loss in the annual total yield. The fungal diseases like Fusarium wilt ( $F$. oxysporum), Verticillium wilt (Verticillium dahliae) and Alternaria leaf spot (Alternaria macrospora) of cotton, causes wilt and lesions on whole plant ${ }^{[4]}$. Hence, heavy loss in the yield of fiber is regularly observed. While the insect resistant transgenic cotton has made a great impact on cotton cultivation around the world, fungal disease resistant transgenic cotton has not reached the world market yet. The above concerns have led to genetic engineering of cotton for improved fungal resistance.

In the present investigation, we planned to use rice chitinase gene for the fungal resistant cotton production. Among various fungal resistant genes, chitinase genes are potentially most promising as the enzymes degrade the substrate chitin found in the fungal cell wall. Hence, genetic engineering of plants with chitinase gene is attractive for fungal disease control mechanism. Several reviews and research articles have also stressed the advantages of using chitinases for plant protection because these enzymes are fungicidal and part of the plant defense system and not harmful to plants ${ }^{[5]}$. Various protocols have been explored for the transformation of cotton such as meristem transformation $^{[6]}$, particle bombardment ${ }^{[7]}$ and Agrobacterium-mediated transformation ${ }^{[8]}$. Of these methods, only the Agrobacterium-mediated and microprojectile bombardment methods are routinely used in cotton transformation studies ${ }^{[9]}$. Agrobacteriummediated transformation via somatic embryogenesis has been the most common method for transgenic cotton development. It is a multi-step process involving laborintensive work over a 10-12 month period starting from co-cultivation of Agrobacterium culture with explants followed by production and maintenance of hundreds of calli derived from independent transformation events, induction of somatic embryos and development of somatic embryos into normal plantlets ${ }^{[10]}$. In this procedure, the transformation efficiencies are generally low due to the low frequency of embryogenesis and the difficulty in germination of transformed embryos ${ }^{[11]}$. Compared with somatic embryogenesis, the shoot tip mediated regeneration techniques are easy and less time-consuming process ${ }^{[12]}$. In recent years, there has been increasing focus on the use of meristems and shoot axes as the source of tissue explants for transgenic cotton production ${ }^{[13-18]}$. Hence, in the present investigation, we targeted to produce the cotton plantlets with chitinase gene through Agrobacteriummediated transformation protocol by using shoot tip culture technique.

\section{MATERIALS AND METHODS}

Plant regeneration protocol: Plant regeneration was achieved by our earlier method by using shoot tip culture $^{[12]}$. In this protocol, the influence of different forms of cytokinins, auxins and polyamines were tested for mass multiplication and regeneration of cotton. In the above protocol, media fortified with MS salts; B5 vitamins; $30 \mathrm{~g} \mathrm{~L}^{-1}$, glucose; 2.0, 2iP; 2.0, IAA $20 \mathrm{mg} \mathrm{L}^{-1}$ putrescine and $0.7 \%$ agar showed a superior response for multiple shoot induction from shoot tip explants. Elongation of shoots was achieved on multiple shoot induction medium itself. Significant numbers of roots were initiated in the medium supplemented with MS salts, vitamin B5, IBA (2.0) and PVP $\left(10 \mathrm{mg} \mathrm{L}^{-1}\right)$. These plantlets were hardened by using sand, soil and vermiculate in 1:1:1 ratio. The hardened plants were transferred to the environmental growth chamber for proper acclimatization. The hardened plants were then transferred to field for boll yielding and they exhibited $95 \%$ survival rate.

\section{Transformation experiments:}

Pre-culture of explants: Pre-culture is an important step involved in Agrobacterium-mediated transformation. The process of pre-incubation makes the explant tissue competent enough to withstand the bacterial infection and other related stress caused during the preculture period in vitro. The shoot tip explants were pre-cultured on the multiple shoot induction medium, for 1-6 days prior to selection on the Phosphinothricin (PPT) containing medium. The sensitivity of the shoot tip explants to PPT was determined by culturing the explants in multiple shoot induction medium along with PPT at different concentrations (1-10 $\left.\mathrm{mg} \mathrm{L}^{-1}\right)$.

Agrobacterium strain and plasmid: Construct pCambia-bar-Chi II (13.8 kb) harbored in strain LBA 4404 of Agrobacterium tumefaciens was used (Fig. 1). Selectable markers were the phosphinothricin acetyl transferase gene (bar) and the hygromycin phosphotransferase (hpt). Both selectable marker genes were driven by the cauliflower mosaic virus (CaMV) 35S promoter. The chitinase gene, Chi 11 $(1.1 \mathrm{~kb})$, was controlled by the maize ubiquitin 1 (ubi1) promoter $(2.0 \mathrm{~kb})$. The ubi-chi11 fragment $(3.1 \mathrm{~kb})$ was released by digesting the construct with Hind III. 
Am. J. Biochem. \& Biotech., 5 (2): 63-74, 2009

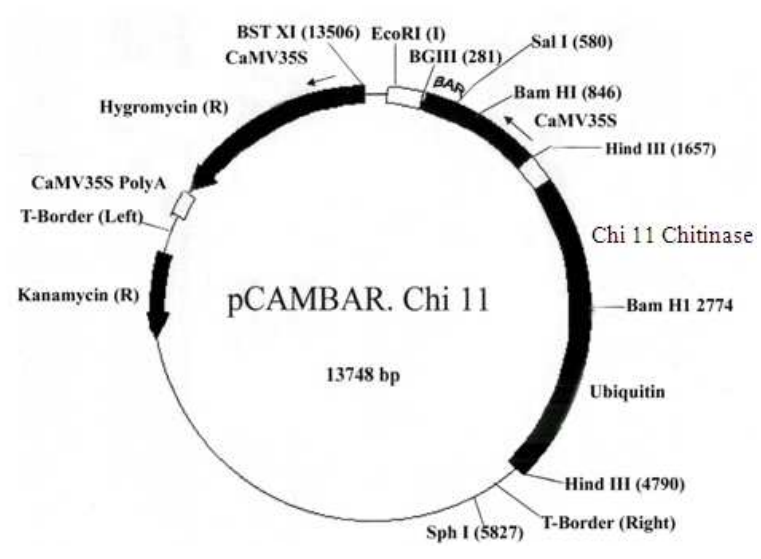

Fig. 1: Diagrammatic representation of complete map of pCAMBIA Bar = Ubi-Chi 11 transforming vector used in this study for fungal disease resistant cotton production

The remaining part of the construct was $10.7 \mathrm{~kb}$ in size. After $6 \mathrm{~h}$, the cultures were collected and used for transformation experiments.

Co-cultivation and selection of stable transformants: The Agrobacterium strains were cultured in LB medium (contains 10 Bacto Tryptone, Bacto, 5 Yeast extract and $10 \mathrm{~g} \mathrm{~L}^{-1} \mathrm{NaCl}$ ). Twenty $\mathrm{mL}$ of LB medium plus antibiotics (50 kanamycin and $50 \mathrm{mg} \mathrm{L}^{-1}$ cefotaxime for strain LBA 4404) was inoculated with Agrobacterium and incubated in a $100 \mathrm{~mL}$ Erlenmeyer flask overnight (about $8 \mathrm{~h}$ ) on a shaker set for 180 to $220 \mathrm{rpm}$ at $28^{\circ} \mathrm{C}$. Then $2 \mathrm{~mL}$ of the overnight culture was withdrawn and used to inoculate $50 \mathrm{~mL}$ of $\mathrm{LB}$ medium without antibiotics. After incubation for 4-6 h at $28^{\circ} \mathrm{C}$ with shaking, those cultures were diluted with additional LB medium to a concentration (OD600 1.0) for transformation. Shoot apices were inoculated by placing one drop of Agrobacterium solution onto each shoot apex in co-culture medium and incubating at $28^{\circ} \mathrm{C}$ under dark conditions for 1-6 days. After cocultivation, explants were washed three times with sterile distilled water. Cleaned apices were blotted dry using a sterile paper towel and cultured on the selection medium consisting of 1-6 mg L ${ }^{-1}$ PPT. Shoot apices not inoculated with Agrobacterium were plated on the selection medium as a negative control. The cultures were incubated at a temperature of $28^{\circ} \mathrm{C}$ under an $18 \mathrm{~h}$ photoperiod and sub-cultured every week. The process was repeated until controls (not co-cultivated with Agrobacterium) were died. The surviving shoot apices were transferred to an MS medium without PPT to root the plantlets. Rooted plants were then transferred to soil and grown to maturity in an environmental growth chamber ${ }^{[12]}$. These plantlets were selected for further characterization of transgene expression.

Analysis of $\mathbf{T}_{\mathbf{0}}$ plants: To test the functional expression of the Chi II gene in the $\mathrm{T}_{1}$ progeny, a germination test was performed. Twenty to thirty $\mathrm{T}_{0}$ seeds were collected from self-pollinated transgenic lines $\left(\mathrm{T}_{0}\right)$ as well as non-transgenic plants (control). $\mathrm{T}_{0}$ seeds were germinated on MS basal medium supplemented with $5.0 \mathrm{mg} \mathrm{L}^{-1}$ PPT.

PCR amplification of transgene: The total DNA was extracted from leaves of cotton plant WITH CTAB (cetyl trimethyl ammonium bromide). The isolated precipitate form of nucleic acid contains both DNA and RNA. The RNA was removed by RNAse solution $\left(0.2 \mathrm{mg} \mathrm{mL}^{-1}\right)$ at room temperature for $15 \mathrm{~min}$. DNA was further purified with phenol/chloroform extraction and ethanol precipitation methods. The total DNA was isolated from A. tumefaciens and estimated by using calf thymus DNA as a standard. The plasmid DNA samples were digested with Hind III for 2-4 $\mathrm{h}$ and the plant genomic DNA samples were digested for 8-10 h: Double digestions were carried out by second digestion after the contents of the first reaction were extracted with neutral phenol/chloroform water saturated ether and precipitated with ethanol. DNA isolated from young leaves of putative transgenic plants was used for the PCR analysis. The DNA samples were tested for the presence of the T-DNA region using a pair of chi II specific primers (F) $5 \mathrm{~N}$ GCTTCTACACCTACGACGCCTT-3N, (R) 5NGTAGCGCTTGTAGAACCCGATC-3NO to yield a 584-bp fragment to amplify the 584- bp nptII fragments. DNA was amplified in a Eppendorf PCR System, programmed for a first denaturation step of $2 \mathrm{~min}$ at $94^{\circ} \mathrm{C}$ followed by 45 cycles of $94^{\circ} \mathrm{C}$ for $1 \mathrm{~min}, 35^{\circ} \mathrm{C}$ for $1 \mathrm{~min}$ and $72^{\circ} \mathrm{C}$ for $2 \mathrm{~min}$. After the completion of 45 cycles, a final extension at $72^{\circ} \mathrm{C}$ was carried out for $5 \mathrm{~min}$. The completed reactions were then held at $4^{\circ} \mathrm{C}$ until electrophoresis was done. PCR products were separated by loading 12 of sample and $2 \mu \mathrm{L}$ of loading buffer on a $1.2 \%$ agarose gel prepared with 1.0X TBE buffer. Electrophoresis was preformed at $4-8 \mathrm{v} \mathrm{cm}^{-1}$ in $1 \times \mathrm{TBE}$ or buffer and upon completion of the run: DNA in the gel was stained with ethidium bromide $\left(0.5 \mathrm{Jg} \mathrm{mL} \mathrm{mL}^{-1}\right)$ and viewed under $\mathrm{UV}$ (PDQuest-BioRad).

DNA blot analysis: DNA was extracted as described earlier and polysaccharides were removed with $2 \mathrm{M}$ $\mathrm{NaCl}$ and ethanol. The DNA was digested with HindIII and electrophoresed on a $0.7 \%$ agarose gel ${ }^{[19]}$. DNA 
fragments were transferred to a nylon membrane (Hybond-N+, Boehringer, Laval, Quebec, Canada) and hybridized with a digoxigenin-labeled ubi1-Chi11 fragment to detect presence of the Chil1 gene. The remainder of the construct (pCambia-bar-chi11), after the release of ubi1-Chi11, was labeled with ${ }^{[32]}$ to hybridize with the other part of the DNA sequence in T-DNA.

Quantitative and qualitative measurements of chitinase: Total proteins were isolated from the young leaves of 30-day-old putative transgenic and control plants ${ }^{[20]}$ and stored at $-20^{\circ} \mathrm{C}$ until use. Analysis by SDS-PAGE was carried out by using $1 \mathrm{~mm}$ thick macro gels. Ten micrograms of total proteins were loaded and electrophoresed for approximately $2 \mathrm{~h}$ at $150 \mathrm{~V}$. The gels were then stained with colloidal Coomassie blue (Himedia India Ltd, Mumbai, India) and photographed using a Kodak digital camera ${ }^{[21]}$. Quantitative analysis of chitinase was determined by the leaf specific method ${ }^{[22]}$. In this method, $500 \mathrm{mg}$ of young leaves (30-day-old plants) of each selected plantlets were homogenized on $0.02 \mathrm{M}$ citric acid/0.04 $\mathrm{M}$ sodium phosphate buffer ( $\mathrm{pH}$ 6.8) and centrifuged at $15,000 \mathrm{rpm}$ for $15 \mathrm{~min}$. For the chitinase reaction, $2 \mathrm{~mL}$ of $0.05 \mathrm{M}$ citric acid/0.1 M sodium phosphate buffer ( $\mathrm{pH}$ 6.8) containing $20 \mathrm{mg}$ of carboxymethyl chitin (Himedia India Ltd, Mumbai, India) was mixed with $1 \mathrm{~mL}$ of the crude enzyme solution, incubated with shaking at $37^{\circ} \mathrm{C}$ for $1 \mathrm{~h}$ and the reaction stopped by the addition of $1 \mathrm{~mL}$ of trichloroacetic acid. After centrifugation at $15,000 \mathrm{rpm}$ for $10 \mathrm{~min}$, the concentration of reducing sugars in the supernatant was measured by the Schales method. One unit was defined as the amount of chitinase which produces $1 \mu \mathrm{moL}$ of reducing sugars as $\mathrm{N}$-acetyl- D-glycosamine $\mathrm{min}^{-1}$.

\section{Bioassay for fungal disease resistance:}

Test for Fusarium resistance: Macrospores of Fusarium oxysporum were produced by culturing the fungus, on Czapek yeast extract agar medium. After 14 days of growth, macrospores were harvested by washing the culture surface with $10-20 \mathrm{~mL}$ of distilled water per petri dish using a pressurized hand sprayer. The suspension of spores and mycelial fragments was filtered through one layer of cheesecloth and spore concentrations adjusted to $1 \times 10^{5}$ spores $\mathrm{mL}^{-1}$. Thirtyday-old fully regenerated plants with tertiary roots were hardened in the earthen pots containing soil mixture and fungal spores $(1 \times 105 \text { spores/100 } \mathrm{g} \text { of soil mixture })^{[23]}$. Each plantlet was covered with the plastic bags to prevent inadvertent spore dispersal. The Fusarium wilt of the plants was identified by yellowing of leaves and vascular browning.
Alternaria leaf spot bioassay: Plantlets regenerated through normal tissue culture conditions were selected as control. The resistance of selected and regenerated control plants to A. macrospora was assessed by spraying of spores $\left(2 \times 10^{5}\right.$ spores $\left.\mathrm{mL}^{-1}\right)$ on leaves and maintained under green house conditions without disturbance $^{[24]}$. During maintenance, each plantlet was covered with a polythene bag without touching the leaves. These plants were incubated under normal green house condition. For every $12 \mathrm{~h}$, pathogenecity of A. macrospora was recorded by measuring the lesion area and numbers. After a week, variations in lesion number and size were carefully measured.

Statistical analysis of data: Means and standard errors were used in presenting the data here and the values were assessed by using a parametric Moods median test $^{[25]}$. The data were analyzed for variance by Duncan's Multiple Range Test (DMRT) using the SAS program (SAS Institute, Cary, NC).

\section{RESULTS AND DISCUSSION}

Factors analyzed for high efficiency transformation: Pre-culture of explants: The transformation efficiency can be increased by manipulating either by the explant and/or by the bacterium to enhance virulence. Such manipulations are based on either increasing the number of competent plant cells for transformation by pre-culturing explants or improving the induction of the vir genes by using pre-culture of explants ${ }^{[26]}$. Hence pre-culture of explants must be examined to improve the transformation frequency. During transformation, pre-culture of explants on shoot multiplication and regeneration medium prior to co-cultivation was considered as one of the essential processes. In this experiment, pre-culture of explants in the regeneration medium for 3 days was found to be good for high percentage of response $(72.4 \%)$. Whereas, the explants, which are not pre-cultured, showed only a $24 \%$ response (Fig. 2a).

The impact of selection agent: The use of proper type and concentration of a selection agent in the selection medium is essential to enhance transformation frequency, in which the selection agent that allows only transformed cells or plants to survive. PPT has been extensively used as a selective antibiotic in transformation experiments, mainly because several plant transformation vectors include bar gene as selectable marker. Initially the explants were placed on shoot tip multiplication medium, which contained different concentrations of PPT (1-6 mg L $\left.{ }^{-1}\right)$. The 
cultures, which are not supplemented with any selection agents, were considered as controls. Our results obtained showed that increased concentrations of PPT led to a gradual decline in the shoot regeneration frequency. The lowest frequency of shoot regeneration was noticed on $4 \mathrm{mg} \mathrm{L}^{-1}$ of PPT (4.8\%). In $5 \mathrm{mg} \mathrm{L}^{-1}$ of PPT treatment, absence of shoot formation and explant growth was noticed. Hence, $5 \mathrm{mg} \mathrm{L}^{-1}$ of PPT treatment was considered for selection procedures. The bar gene encodes Phosphinothricin Acetyl Transferase (PAT) that detoxifies PPT by catalyzing the addition of an acetyl group to the free amino group. The efficacy of PPT as a selection marker and bar as a resistance mechanism has resulted in bar being widely exploited in the construction and selection of transgenic plant lines. Similar to our observations, bar gene, which provides resistance to herbicide PPT, has been used successfully as a selectable marker in several plants ${ }^{[27]}$.

Effect of co-cultivation conditions: Transformation efficiency of any explants can be enhanced by cocultivation on shoot regeneration medium at different period (0-6 days). Among them, 3 days co-cultivated shoot tip explants produced significantly higher rate of transformation $(60.1 \%)$ when compared with 0 days and 6 days of co-cultivation. The explant viability was affected after 3 days co-cultivation period (Fig. 2b). Influence of co-cultivation period on Agrobacteriummediated transformation has also been reported in a number of plant species ${ }^{[28]}$. Similar to our results, in these studies co-cultivation of explants for 2-3 days generally provided the best transformation frequency. However, prolonged co-cultivation periods of 6-7 days increased transformation efficiency in flax ${ }^{[29]}$ and a 5 day co-cultivation was the most effective for transient GUS expression in citrange plants ${ }^{[30]}$. The effectiveness of prolonged co-cultivation in some plant species might be due to the increased number of induced bacteria attaching to plant cells and/or the increased number of plant cells competent for Agrobacterium-mediated transformation $^{[29]}$. During co-cultivation, we also evaluated the effect of different concentrations of bacterial concentration (0.75-1.3 OD cultures) on transformation frequency. From the different concentrations, 1.0 OD culture showed a superior response $(70.2 \%)$ and unfortunately above 1.1 OD culture showed a decline in the percentage of response and the explants turned to necrotic and devoid of shoot regeneration due to excessive growth of the bacteria (Fig. 2c). Although cotton transformation rates have been significantly improved, increasing its efficiency on plant recovery is still needed ${ }^{[30]}$. Many factors such as plant genotype, explants type, $\mathrm{pH}$, co-cultivation media,

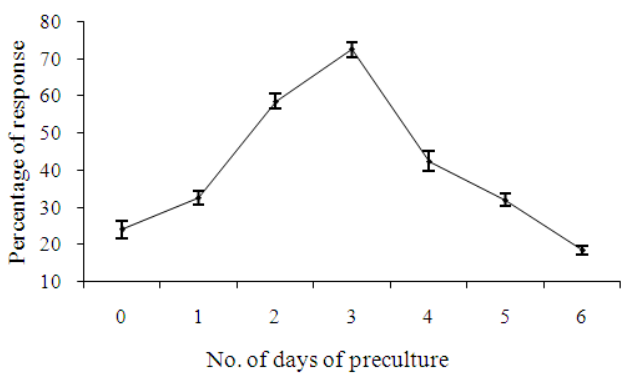

(a)

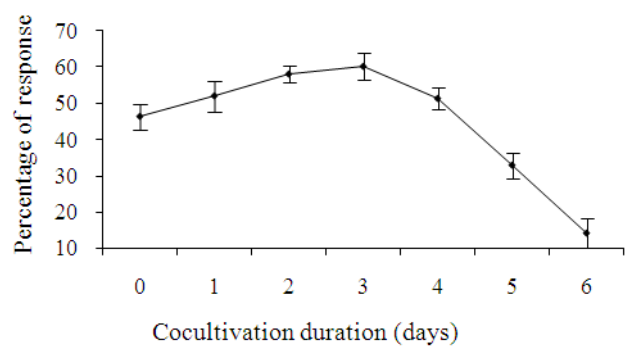

(b)

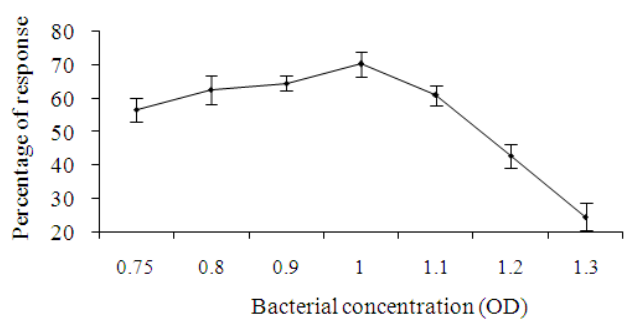

(c)

Fig. 2: The effect of pre-culture days (a): Co-culture duration; (b): And bacterial concentration; (c): On growth response and transformation frequency of shoot tip explants

temperature and period influence the gene transfer efficiency from Agrobacterium to plant cells and the above external factors play a critical role in T-DNA transfer mechanism in particularly vir gene activation $^{[31]}$.

Selection and characterization of transformants: The shoot apices were co-cultivated with A. tumefaciens LBA4404 for 3 days. After cocultivation, the shoot apices were transferred to shoot bud regeneration medium with $5 \mathrm{mg} \mathrm{L}^{-1}$ PPT. Under PPT selection (bar gene), the most of the shoots appeared to be bleached and some of the shoots that were initially green and bleached out gradually, leaving only a few green shoots. After 2 weeks, these green shoot apices were transferred to fresh media for every 2 weeks (Fig. 3a and b). In the PPT supplemented media, 


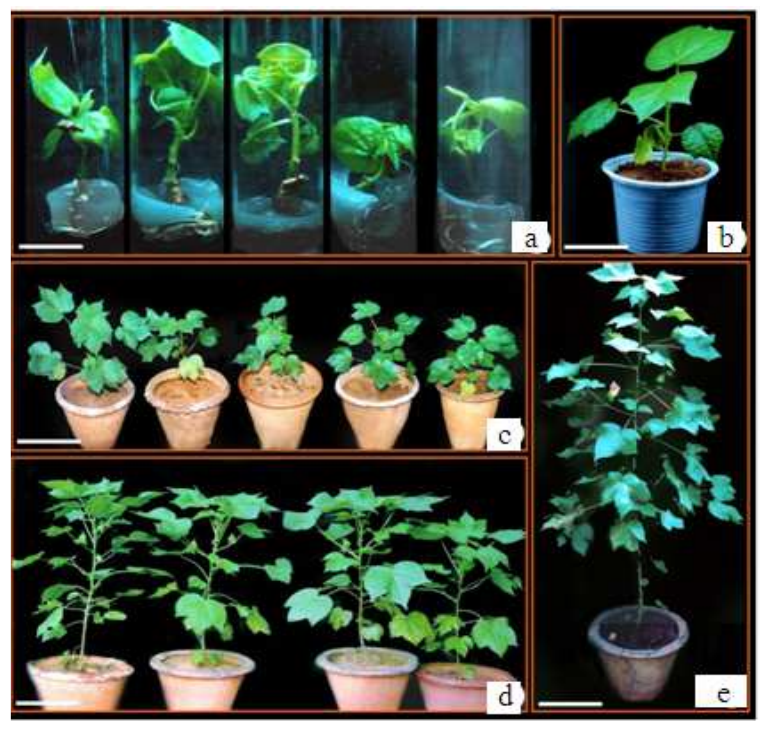

Fig. 3: Different developmental stages of transgenic cotton through shoot tip-mediated direct regeneration; (a): Rooted transgenic shoots containing the secondary and tertiary roots.

$\mathrm{Bar}=2.5$ 츠; (b): Hardened transgenic plantlet grown in plastic pot. $B a r=5 \mathrm{~cm}$; (c): One month old well developed transformed plantlets established in earthen pots. $\mathrm{Bar}=15 \mathrm{~cm}$; (d): Two months old transformed plantlets. Bar $=20 \mathrm{~cm}$; (e): Transgenic plantlet with flowers and bolls. $\mathrm{Bar}=20 \mathrm{~cm}$

declines trend was recorded for multiple shoot induction percentage, when compared with control cultures (Fig. 3c). After 10 weeks of selection, surviving shoots were transferred to MS media without PPT to induce rooting (Fig. 3d). Rooted plantlets were first transferred to plastic pots and grown in an environmental growth chamber (Fig. 3e-h).

During selection procedure, 10 independent experiments were carried out. After the completion of transformation procedure, the plantlets harvested in the PPT containing selection media were considered as putative transgenic plants. The morphological features of the transgenic plants did not differ from those of non-transgenic plants. After root induction, in the 10 experiments the transformation efficiency was $21.4 \%$. In contrast, for the 25 shoot apices not treated with Agrobacterium, died on PPT selection $\left(5 \mathrm{mg} \mathrm{L}^{-1}\right)$. The Agrobacterium strain used had a major effect on transformation efficiency of cotton. It was found that the use of strain LBA4404 yielded a higher degree of transformation efficiency in cotton. This is in agreement with the previous report on cotton transformation ${ }^{[8]}$.
Table 1: Transformation efficiency of regenerated plantlets on shoot tip regeneration medium fortified with selection marker (PPT $5 \mathrm{mg} \mathrm{L}^{-1}$ )

\begin{tabular}{llll}
\hline Sample & $\begin{array}{l}\text { Total Number of } \\
\text { explants tested } \\
\text { (10 experiments) }\end{array}$ & $\begin{array}{l}\text { Total number of plantlets } \\
\text { showing resistant to } \\
\text { selection marker }\end{array}$ & $\begin{array}{l}\text { Transformation } \\
\text { efficiency }\end{array}$ \\
\hline $\begin{array}{l}\text { Non- } \\
\text { transformed }\end{array}$ & 25 & 0 & 0 \\
Transformed & $392 \pm 5.72$ & $84 \pm 2.37$ & $21.4 \pm 075$ \\
\hline
\end{tabular}

Table 2: Segregation analysis in progeny of the primary transformants $\left(\mathrm{T}_{0}\right)$ of the three cotton varieties as assessed by the PPT sensitivity test $\left(5.0 \mathrm{mg} \mathrm{L}^{-1}\right)$

\begin{tabular}{|c|c|c|c|c|}
\hline Sample seeds & $\begin{array}{l}\text { No. of } \\
\text { seeds tested }\end{array}$ & $\begin{array}{l}\text { No. of seeds } \\
\text { germinated }\end{array}$ & $\begin{array}{l}\text { Death of } \\
\text { seedlings }\end{array}$ & $\begin{array}{l}\text { Growth ratio on } \\
\text { selection media } \\
\text { (transformed/ } \\
\text { non-transformed) }\end{array}$ \\
\hline Non-transformed & 24 & 0 & 0 & 0 \\
\hline SVPR2-Chi-1 & 26 & 20 & 6 & $3.3: 1$ \\
\hline SVPR2-Chi-15 & 21 & 16 & 5 & $3.2: 1$ \\
\hline SVPR2-Chi-31 & 16 & 12 & 4 & $3: 1$ \\
\hline SVPR2-Chi-45 & 20 & 15 & 5 & $3: 1$ \\
\hline SVPR2-Chi-62 & 28 & 21 & 7 & $3: 1$ \\
\hline
\end{tabular}

The transformed shoots grew up to 7-8 $\mathrm{mg} \mathrm{L}^{-1}$ of PPT treatment and further increase led to shoot death (Table 1). Finally, 84 plantlets were germinated on the selection medium. These lines (SVPR2-Chi-1, SVPR2Chi -2, -3-SVPR2-Chi-84) were used for further analyses. Transformants had similar morphological characteristics to non-transformants, except that SVPR2-Chi-24, -42 and -59 had somewhat smaller phenotypes.

Analysis of $\mathbf{T}_{0}$ progeny: Seeds obtained from $\mathrm{T}_{0}$ were germinated to raise the $T_{1}$ plants and these were tested for the presence of the Chi II gene. The inheritance of the introduced genes in the $T_{1}$ generation in the variety was studied using in vitro seed germination test on seed germination media containing $5 \mathrm{mg} \mathrm{L}^{-1}$ PPT. The untransformed plant seeds showed nil response for germination on selection media. For the transformed lines tested; SVPR2-Chi-1, SVPR2-Chi- 15, SVPR2Chi-31, SVPR2-Chi-45 and SVPR2-Chi-62, the ratio of resistant to non-resistant plants was equal or close to 3:1 (Table 2). The presence of transgene was further confirmed in the $T_{1}$ generation by PCR amplification. In previous reports on progeny analysis of transgenic cotton, a segregation ratio of $3: 1$ was reported.

This ratio was expected for a single gene trait. The gene was the CryIA (b) gene from Bacillus thuringiensis (Bt) for insect resistance, regulated by the CaMV 35S promoter. Like our experiments, the $\mathrm{T}_{1}$ progeny expressed the Bt gene as a single dominant Mendelian trait in 3:1 $\mathrm{ratio}^{[3]}$. 
Am. J. Biochem. \& Biotech., 5 (2): 63-74, 2009

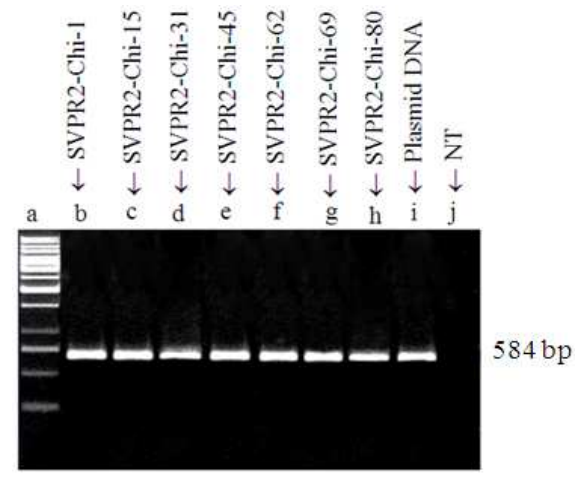

Fig. 4: PCR analysis of DNA isolated from leaves of independent transformants of cotton and nontransformed control plant. Agarose gel electrophoresis of PCR amplification was performed with primers for the Chi II gene; (Lane a): Molecular size marker (Lanes b-h): DNA from transformed plants showing the expected 584 bp; (Lane i): Positive control (DNA from plasmid DNA of A. tumefaciens); Lane (j): DNA from untransformed plant

\section{Confirmation of transformants:}

PCR analysis: Leaf DNA isolated from 7 randomly selected putative $\mathrm{T}_{0}$ plants (SVPR2-Chi-1, SVPR2-Chi15, SVPR2-Chi-31, SVPR2-Chi-45, SVPR2-Chi-62, SVPR2-Chi-69 and SVPRChi-80) and non-transformed control plants were analyzed for PCR amplification of the Chi II. The presence of a band at $584 \mathrm{bp}$ in samples from transformed plants confirmed the integration of the chitinase gene (Fig. 4 Lanes b-h). Amplification of this fragment (584 bp) was not observed in nontransformed control plants (Fig. 4: Lane j). These observations indicated that the Chi II gene had been integrated into the genome of the transformed shoots of $\mathrm{T}_{0}$ progeny thereby confirming transformation. Some reports proved that the shoot tip/meristem transformation protocols, albeit genotype-independent, are extremely laborious and generate a high frequency of chimeras ${ }^{[18,32]}$. Our experiments on PCR analysis proved that chimera formation significantly reduced and the randomly selected 6 plantlets showed PCR positive results. $\mathrm{T}_{0}$ support our PCR experiments, low percentage of chimera formation was noticed by using shoot tip explants ${ }^{[33]}$.

Southern blot analysis: The southern hybridization was done by using restricted DNA and probed with $0.58 \mathrm{~kb}$ Chi II gene and results showed the presence of chi II gene in the $\mathrm{T}_{1}$ plants (SVPR2-Chi-1, SVPR2-Chi31, SVPR2-Chi-45 and SVPR2-Chi-62) (Fig. 5: Lanes c-f). The Chi II gene was not detectable in the nontransformed plants (control) (Fig. 5 Lane a and b).

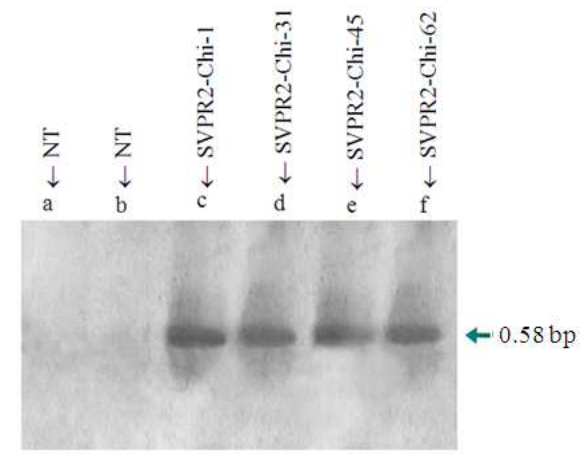

Fig. 5: Southern blot analysis of DNA isolated from leaves of untransformed control and independent transformants; (Lane $\mathrm{a}$ and $\mathrm{b}$ ): Total genomic DNA of non-transformed plants (Lane c-f): DNA from transformed plants showing $0.58 \mathrm{~Kb}(\lambda$-DNA digested with HindIII and probed with $0.58 \mathrm{~Kb}$ Chi II)

In the Hind III digestion, a positive band was observed in all the lines as expected. This result also confirmed the PCR results and indicated the integration of the TDNA region in the transgenic plants of $T_{1}$ genome. No variation in number of copies of the chi II gene was observed between the transgenic plants examined. In this study, a significant number of cotton plants carrying the chitinase (Chi11) gene have been produced using the Agrobacterium transformation system. These results represent a convincing confirmation of Agrobacterium-mediated transformation of cotton and showed the potential reproducible protocol for genetic engineering of Indian cotton. The frequencies of transformation obtained in this study seem to be equal or slightly higher than other systems of transformation, although genotypic differences were observed ${ }^{[18]}$.

Expression of chitinase: Qualitative and quantitative analysis were also performed for chitinase gene expression. Differences in extracellular protein profile between the transformed and non-transformed control was observed on SDS-PAGE gels at $36 \mathrm{kDa}$ levels (Fig. 6). In the selected two lines SVPR2-Chi-1 and SVPR2-Chi-69 over expression of $36 \mathrm{kDa}$ was recorded and it was due to the integration of Chi11 in cotton genome (Fig. 6 Lanes c and d). In the case of control non-transformed plantlets very low level of $36 \mathrm{kDa}$ protein was observed (Fig. 6 Lanes a and b). Based on SDS-PAGE experiments, quantitative analysis showed an 18-21-fold increase in chitinase enzyme activity in the transformed lines (SVPR2-Chi-1, SVPR2-Chi-15, SVPR2-Chi-31, SVPR2-Chi-45, SVPR2-Chi-62 and SVPR2- Chi-69). In all the selected transformed lines, 
Am. J. Biochem. \& Biotech., 5 (2): 63-74, 2009

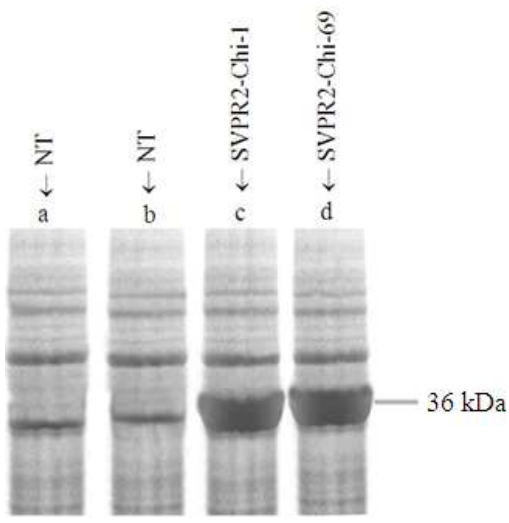

Fig. 6: Variations in the extracellular leaf proteins of 30-day-old plants by SDS-PAGE on transformed and non-transformed cotton plantlets. The gels were stained with coomassie blue; (Lanes a and b): Leaf protein profile of control plants; (Lanes $\mathrm{c}$ and $\mathrm{d}$ ): Leaf protein profile of transformed cotton plantlets showing expected $36 \mathrm{kDa}$ chitinase activity

Table 3: Analysis of chitinase activity in 30-day-old leaves of transformed lines of cotton

\begin{tabular}{lc}
\hline Sample & Glu NAc* $\left(\mathrm{mU} \mathrm{g}^{-1}\right.$ fresh weight $)$ \\
\hline Non-transformed & $6 \pm 1.2$ \\
SVPR2-Chi-1 & $135 \pm 4.2$ \\
SVPR2-Chi-15 & $135 \pm 3.8$ \\
SVPR2-Chi-31 & $125 \pm 4.0$ \\
SVPR2-Chi-45 & $145 \pm 5.1$ \\
SVPR2-Chi-62 & $140 \pm 5.4$ \\
\hline
\end{tabular}

*: N-Acetyl-D-glucosamine, values are means \pm SE of four repeated experiments

enhanced expression of chitinase was observed (Table 3). Enhanced expression of chitinases in plants is commonly observed under the stressed conditions as well as in pathogen infection. These plant chitinases degrade chitin in fungal cell walls and can inhibit the infectious fungal growth ${ }^{[34]}$. Extracellular chitinases may directly block the growth of the hyphae invading intercellular spaces and possibly release fungal elicitors, which then induce additional chitinase biosynthesis and further defense reactions in the host ${ }^{[35]}$.

\section{Bio-assay for disease resistance in transformed plantlets:}

Analysis for Fusarium wilt resistance: For Fusarium wilt resistance analysis, the survival percentage of control (non-transformed plantlets) was significantly affected by the inoculation of Fusarium macrospores (1×105 spores/100 $\mathrm{g}$ of soil mixture) during hardening (Table 4). All the 7 PCR positive plants showed healthy regeneration in fungal spore inoculated soil (SVPR2Chi-1, SVPR2-Chi-15, SVPR2-Chi-31, SVPR2-Chi-45,
Table 4: Survival rate of PCR positive plantlets and control plants on earthen pots inoculated with $5 \times 10^{5}$ spores $\mathrm{mL}^{-1}$ of Fusarium oxysporum

\begin{tabular}{llll}
\hline $\begin{array}{l}\text { No. of days } \\
\text { after inoculation } \\
\text { of spores }\end{array}$ & $\begin{array}{l}\text { Survival rate of } \mathrm{T}_{1} \text { plantlets } \\
-\mathrm{C}(25)\end{array}$ & $\mathrm{Ci}(25)$ & PCR positive plantlets (6) \\
\hline 4 & $25 \mathrm{a}$ & $25 \mathrm{a}$ & $6 \mathrm{a}$ \\
8 & $23 \mathrm{~b}$ & $12 \mathrm{~b}$ & $6 \mathrm{a}$ \\
12 & $23 \mathrm{~b}$ & $2 \mathrm{c}$ & $6 \mathrm{a}$ \\
16 & $23 \mathrm{~b}$ & 0 & $6 \mathrm{a}$ \\
20 & $23 \mathrm{~b}$ & 0 & $6 \mathrm{a}$ \\
40 & $23 \mathrm{~b}$ & 0 & $6 \mathrm{a}$ \\
\hline
\end{tabular}

C: Non-transformed plantlets without spore inoculation; Ci: Control plantlets inoculated with macroconidia; Means within a column followed by the same letters are not significant at $p=0.05$ according to DMRT

Table 5: Variations in lesion size and number and wilted area of transformed and non-transformed plants sprayed with Alternaria macrospora spores $\left(5 \times 10^{5}\right.$ spores $\left.10^{-1} \mathrm{~mL}\right)$

\begin{tabular}{|c|c|c|c|c|}
\hline \multirow{2}{*}{$\begin{array}{l}\text { No. of days } \\
\text { after inoculation } \\
\text { of spores }\end{array}$} & \multicolumn{2}{|l|}{ Leaf spots /leaf } & \multicolumn{2}{|c|}{ Lesion length $(\mathrm{mm})$} \\
\hline & $\begin{array}{l}\text { PCR positive } \\
\mathrm{Ci}(\mathrm{Nt})\end{array}$ & plantlets & $\begin{array}{l}\text { PCR positive } \\
\mathrm{Ci}(\mathrm{Nt})\end{array}$ & Plantlets \\
\hline 4 & $8.5 \pm 0.96 \mathrm{e}$ & 0 & $2.2 \pm 0.21 \mathrm{c}$ & 0 \\
\hline 8 & $25.8 \pm 1.85 \mathrm{~d}$ & 0 & $5.4 \pm 0.18 \mathrm{~b}$ & 0 \\
\hline 12 & $27.2 \pm 2.5 \mathrm{c}$ & 0 & $5.8 \pm 0.29 \mathrm{~b}$ & 0 \\
\hline 16 & $32.8 \pm 2.4 \mathrm{~b}$ & 0 & $5.8 \pm 0.32 \mathrm{~b}$ & 0 \\
\hline 20 & $34.9 \pm 3.12 \mathrm{a}$ & 0 & $5.8 \pm 0.10 \mathrm{a}$ & 0 \\
\hline
\end{tabular}
transformed Values are means \pm SE of four repeated experiments; Means within a column followed by the same letters are not significant at $\mathrm{p}=0.05$ according to DMRT

SVPR2-Chi-62 and SVPR2-Chi-69). These plants were finally selected as Fusarium wilt tolerant plants. Consistent with the above results, vascular browning was observed only in control cultures inoculated with spores of $F$. oxysporum. At the same time vascular browning was completely absent in the transformed plants. The regenerated control plantlets showed 95\% survival rate under normal environmental conditions. All the selected disease tolerant plants showed equal regeneration potential when compared with controls.

Alternation leaf spot assay: Randomly selected two PCR positive plantlets (50 days old) (SVPR2-Chi-1 and SVPR2-Chi-69) showing resistance to Fusarium wilt were also analyzed for Alternaria leaf spot resistance. The control and PCR positive plantlets were sprayed with Alternaria spores. All the 10 control plants showed signs of susceptibility; they developed a larger number of lesions with greater size compared to the transformed plantlets. However, selected transformed plantlets showed $100 \%$ disease resistance for up to 30 days. In the non-transformed plantlets, the lesion number and length increased to 34.9 and 5.8, respectively after 20 days of inoculation (Table 5). The bioassay of the $\mathrm{T}_{0}$ PCR and Southern-positive plants 
Am. J. Biochem. \& Biotech., 5 (2): 63-74, 2009

with Fusarium oxysporum and Alternaria macrospora showed that the infection level was significantly controlled in transgenic progenies having a higher expression of PR-proteins than in the non-transgenic control plants, indicating enhanced resistance to Fusarium wilt and Alternaria leaf spot diseases. Usually, in the transformed plants, variations in disease resistant among individual $T_{1}$ plants were recorded. This is most probably due to different amounts of chitinase production. Our experiments showed that there is not significant variation in disease resistance among the $\mathrm{T}_{1}$ plants obtained.

The rapid development of transgenic cotton production technology not only provides a valuable method for introducing useful genes into cotton to improve important agronomic traits, but also helps in the evaluation of mechanism, function and regulation of gene(s). The present investigation was aimed to standardize the simple and reproducible protocol in transgenic cotton regeneration for fungal disease tolerance. In this study, a large number of cotton plants carrying the rice chitinase (Chil1) gene have been produced using the Agrobacterium transformation system. These results represent a convincing confirmation of Agrobacterium-mediated transformation of cotton and show the potential of this technique for genetic engineering of Indian cotton. The frequencies of transformation obtained in this study seem to be equal to other systems of transformation (protoplast and biolistic) used to obtain transgenic cotton, although genotypic differences must be considered ${ }^{[9]}$. Selection markers mediated inheritance studies on $T_{1}$ progeny showed that the chitinase gene is transmitted to the $T_{1}$ progeny, demonstrating stable incorporation of T-DNA into the cotton nuclear DNA and the 3:1 segregation ratio suggested that the chitinase gene was integrated at a single locus. Previously, three reports were published on transgenic cotton with chitinase gene. Those studies, they used tobacco chitinase $^{[36]}$ : Fungal chitinase of Trichoderma virens ${ }^{[37]}$ and bean chitinase ${ }^{[9]}$ to control the fungal pathogens Verticillium dahliae, Rhizoctonia solani, Alternaria macrospora and A. alternate respectively ${ }^{[38]}$. These reports are relevant to American and Turkey cotton varieties due to genotype dependent responses. Unfortunately, in Indian varieties no reports were published for transgenic cotton production for fungal disease tolerance. Hence, the present study on production of transgenic cotton with chitinase gene is important. In cotton, like chitinase gene transformation, different antifungal genes were also transferred for fungal disease tolerance. Transgenic cotton expressing the chloroperoxide or D4E1 genes showed antifungal activity against Aspergillus flavus and Verticillium dahliae ${ }^{[39]}$. The expression of 14-kDa Corn trypsin inhibitor gene was also showed resistance to A. flavus $^{[40]}$. Similar to the above attempt, transgenic cotton plants harboring Talaromyces flavus GO gene results notable resistance against root pathogen Verticillium dahliae ${ }^{[41]}$.

Similar to our observations, the enhanced resistance against fungal pathogens was obtained when the plants were engineered with chitinase genes. In all the economically important plants, the yield was directly affected by the fungal pathogens ${ }^{[11]}$. Mostly chitinases causes hyphal tips lyse in vitro. Some chitinases are having isozymal activities and can hydrolyze the peptides in bacterial cell wall, whereas others have exohydrolytic activity ${ }^{[42]}$. Rice was the first plant species transformed with chitinase gene, (Chi II). A chitinase gene isolated form rice genomic library was placed under the control of CaMV 35S promoter in rice protoplasts under PEG-mediated transformation ${ }^{[43]}$. They identified one to six copies of chitinase transgene in rice plant through Southern blot analysis. The level of expression varied over 15 -fold range between the each selected individual transgenic plants. Expression of the chitinase was observed in almost all the part of transgenic plants (root, sheath and leaves). Several crop plants were also transformed with chitinase gene for improved disease tolerance. For example, transgenic cucumber plants with Chi-II gene showed enhanced disease resistance against gray mold ${ }^{[44]}$. In strawberries also increased resistance to the Sphaerotheca humuli was observed ${ }^{[22]}$. Similarly, $13-43 \%$ reduction in the development of block spots in transgenic rose plants was observed by basic class I chitinase gene ${ }^{[24]}$. A very few transgenic plant species expressing chitinases have been evaluated in field trails and it was proved that disease incidence was reduced ${ }^{[45]}$. On the other hand, some reports showed that transgenic plants over expressing chitinase do not have resistance to some fungal diseases. For example, transgenic tobacco (Nicotiana sylvestris) containing a tobacco class I chitinase gene does not have increased resistance to Cercospora nicotianae, although it has increased chitinase enzyme activity ${ }^{[46]}$. Transgenic tobacco (Nicotiana benthamiana) harboring a class III chitinase from sugar beet also did not have increased resistance against Cercospora beticola ${ }^{[47]}$. The resistance in these transformants most likely depends on several factors, including the catalytic specificity or localization of chitinase and the characteristic state or infection behavior of the fungi. Advances in regeneration and transformation protocols have led to the successful development of transgenic cotton with improved 
agronomic characters. There are several types of fungal resistance genes that were used for disease resistance of plants $^{[48,49]}$ : Among them chitinase was proved as one of the best fungal resistant genes.

\section{CONCLUSION}

In our studies, we obtained a significant improvement in the percentage of plant regeneration for transformed plants and recovery of transgenic plants resistant to two fungal pathogens. Limitations associated with somatic embryogenesis protocol make the present protocol more suitable for rapid development of transgenics in recalcitrant system-like cotton and the method will be useful for genetic engineering of cotton for various agronomical traits including fungal resistance.

\section{ACKNOWLEDGEMENT}

The researchers would like to thank Dr. S. Muthukrishnan, Biochemistry Department, Kansas State University, USA for kindly providing the vector and Dr. Pill-Soon Song, Distinguished chair Professor, Faculty of Biotechnology, Cheju National University, Jeju, South Korea for language improvement of this manuscript.

\section{REFERENCES}

1. Vander Jagt, D.L., L.M. Deck and R.E. Royer, 2000. Gossypol prototype of inhibitors targeted to dinucleotide folds. Curr. Med. Chem., 7: 478-498. DOI: $10.2174 / 0929867003375119$

2. Benedict, J.H. and D.W. Altman, 2001. Commercialization of Transgenic Cotton Expressing Insecticidal Crystal Protein. In: Genetic Improvement of Cotton. Jenkins, J.N. and S. Saha (Eds.). USDA-ARS, Oxford and IBH, New Delhi, India, pp: 136-201.

3. Perlak, F.J., R.W. Deaton, T.A. Armstrong, R.L. Fuchs, S.R. Sims, J.T. Greenplate and D.A. Fischoff, 1990. Insect resistant cotton plants. Biotechnology, 8: 939-943. DOI: 10.1038/nbt1090-939

4. Cui, Y., A.A. Bell, O. Joost and C. Magill, 2000. Expression of potential defense response genes in cotton. Physiol. Mol. Plant Pathol., 56: 25-31. DOI: 10.1006/pmpp.1999.0245

5. Collinge, D.B., K.M. Kragh, J.D. Mikkelsen, K.K. Nielsen, U. Rasmussen and K. Vad, 1993. Plant chitinases. Plant J., 3: 31-40. DOI: 10.1111/j.1365-313X.1993.tb00008.x
6. Zapata, C., S.H. Park, K.M. El-Zik and R.M. Smith, 1999. Transformation of a Texas cotton cultivar by using Agrobacterium and the shoot apex. Theor. Applied Genet. $\quad$ 98: 252-256. http://cat.inist.fr/?aModele $=$ afficheN\&cpsidt $=1697015$

7. Rajasekaran, K., R.L. Hudspeth, J.W. Cary, D.M. Anderson and T.E. Cleveland, 2000. High frequency stable transformation of cotton (Gossypium hirsutum L.) by particle bombardment of embryogenic cell suspension cultures. Plant Cell Rep., 19: 539-545. DOI: 10.1007/s002990050770

8. Umbeck, O., G. Hohnson, K. Barton and W. Swain, 1987. Genetically transformed cotton (Gossypium hirsutum L.). Plant Biotechnol., 5: 263-266. DOI: 10.1038/nbt0387-263

9. Tohidfar, M., M. Mohammadi and B. Ghareyazie, 2005. Agrobacterium-mediated transformation of cotton (Gossypium hirsutum) using a heterologous bean chitinase gene. Plant Cell Tiss. Organ Cult., 83: 83-96.

http://cat.inist.fr/?aModele $=$ afficheN\&cpsidt $=1705$ 0388

10. Ganesan, M. and N. Jayabalan, 2004. Evaluation of haemoglobin for improved somatic embryogenesis and plant regeneration in cotton (Gossypium hirsutum cv. SVPR 2). Plant Cell Rep., 23: 181-187. DOI: 10.1007/s00299-004-0822-y

11. Wilkins, T.A., K. Rajasekaran and D.M. Anderson, 2000. Cotton biotechnology. Crit. Rev. Plant Sci., 19: 511-550.

http://direct.bl.uk/bld/PlaceOrder.do?UIN=088424 $372 \&$ ETOC $=$ RN\&from $=$ searchengine

12. Ganesan, M. and N. Jayabalan, 2006. Influence of cytokinins, auxins and polyamines on in vitro mass multiplication of cotton (Gossypium hirsutum L. cv. SVPR2). Ind. J. Exp. Biol., 44: 506-513. http://www.ncbi.nlm.nih.gov/pubmed/16784123

13. McCabe, D.E. and B.J. Martinell, 1993. Transformation of elite cotton cultivars via particle bombardment of meristems. Biotechnology, 11: 596-598. DOI: 10.1038/nbt0593-596

14. Gould, J., Y. Zhou, Y. Shen, M. MagallanesCedeno and J. Luo, 1997. Shoot apex transformation of cotton using Agrobacterium. Proceedings of the Conferences on Beltwide Cotton Production, (CBCP'97), National Cotton Council, Memphis TN., pp: 432. http://www.fao.org/agris/search/display.do?f=./199 8/v2403/US1997053255.xml;US1997053255

15. Keller, G., L. Spatola, D. McCabe, B. Martinell, W. Swain and M.E. John, 1997. Transgenic cotton resistant to herbicide bialaphos. Transgen. Res., 6: 385-392. DOI: 10.1023/A:1018483300902 
Am. J. Biochem. \& Biotech., 5 (2): 63-74, 2009

16. Gould, J.H. and M. Magallances-Cedeno, 1998. Adaptation of cotton shoot apex culture to Agrobacterium-mediated transformation. Plant Mol. Biol. Rep., 16: 283-289. http://pubs.nrccnrc.gc.ca/ispmb/16283-3.html

17. Zhang, B.H., F. Liu and C.B. Yao, 2000. Plant regeneration via somatic embryogenesis in cotton. Plant Cell Tiss. Organ Cult., 60: 89-94. DOI: 10.1023/A:1006488119200

18. Satyavathi, V.V., V. Prasad, B. Gita Lakshmi and G. Lakshmi Sita, 2002. High efficiency transformation protocol for three Indian cotton varieties via Agrobacterium tumefaciens. Plant Sci., 162: 215-220.

http://cat.inist.fr/?aModele=afficheN\&cpsidt=13447997

19. Agharbaoui, Z., A.F. Greer and Z. Tabaeizadeh, 1995. Transformation of the wild tomato Lycopersicon chilense Dun. By Agrobacterium tumefaciens. Plant Cell Rep., 15: 102-105. http://cat.inist.fr/?aModele $=$ afficheN\&cpsidt $=2948$ 388

20. Gavish, H., A. Vardi and R. Fluhr, 1991. Extracellular proteins and early embryo development in citrus nucellar cell culture. Physiol. Plant, 82: 606-616. DOI: 10.1111/j.13993054.1991.tb02954.x

21. Laemmili, U.K., 1970. Cleavage of structural proteins during the assembly of the head of bacteriophage T4. Nature, 227: 680-685. http://www.ncbi.nlm.nih.gov/pubmed/5432063

22. Asao, H., Y. Nishizawa, S. Agai and T. Sato, 1997. Enhanced resistance against a fungal pathogen Phaerotheca humuli in transgenic strawberry expressing a rice chitinase gene. Plant Biotechnol., 14: 145-149.

http://www.jspcmb.jp/english/pbcontents/pb14_3.h tml

23. Mandavia, M.K., C.M. Patel, G.V. Maravia and M. Parameswaran, 1997. Role of phenolic compounds in resistance to Fusarium wilt in Chickpea. Ind. J. Agric. Biochem., 10: 11-13. http://www.indianjournals.com/ijor.aspx?target=ijo r:ijab\&type $=$ home

24. Marchant, R., M.R. Davey, J.A. Lucas, C.J. Lamb, R.A. Dixon and J.B. Power, 1998. Expression of a chitinase transgene in rose (Rosa hybrida L.) reduces development of blackspot disease (Diplocarpon rosae Wolf). Mol. Breed., 4: 187-194. DOI: 10.1023/A:1009642707505

25. Snedecor, G.W. and W.G. Cochran, 1989. Statistical Methods. 8th Edn., Iowa State University Press, Ames, ISBN: 10: 0813815614, pp: 305 .
26. Veluthambi, K., M. Krishnan, J.H. Gould, R.H. Smith and S.B. Gelvin, 1989. Opines stimulate induction of the vir genes of the Agrobacterium tumefaciens Ti plasmid. J. Bacteriol., 171: 3696-3703. http://www.pubmedcentral.nih.gov/articlerender.fc gi? artid=210113

27. Halluin, D.K., M. De Block, J. Denecke, J. Janssens, J. Leemans, A. Reynaerts and J. Botterman, 1992. The bar gene as selectable and screenable marker in plant engineering. Methods Enzymol., 216: 415-426. http://www.ncbi.nlm.nih.gov/pubmed/1479912

28. Mohan, K.L. and K.V. Krishnamurthy, 2003. Plant regeneration from decapitated mature embryo axis and Agrobacterium-mediated genetic transformation of pigeon pea. Biol. Plant, 46: 519-527. http://cat.inist.fr/?aModele $=$ afficheN\&cpsidt $=15060957$

29. Dong, J.Z. and A. McHughen, 1991. Patterns of transformation intensity on flax hypocotyls inoculated with Agrobacterium tumefaciens. Plant Cell Rep., 10: 555-560. DOI: 10.1007/BF00232510

30. Cervera, M., J.A. Pina, J. Juarez, L. Navarro and L. Pena, 1998. Agrobacterium-mediated transformation of citrange: Factors affecting transformation and regeneration. Plant Cell Rep., 18: 271-278.

http://cat.inist.fr/?aModele $=$ afficheN\&cpsidt $=1602$ 837

31. Dillen, W., J. De Clercq, J. Kapila, M. Zambre, M. Van Montagu and G. Angenent, 1997. The effect of temperature on Agrobacterium tumefaciensmediated gene transfer to plants. Plant J., 12: 1459-1463.

http://direct.bl.uk/bld/PlaceOrder.do?UIN=037322 210\&ETOC $=$ RN\&from $=$ searchengine

32. Majeed, A., T. Husnain and S. Riazuddin, 2000. Transformation of virus resistant genotype of Gossypium hirsutum L. with pesticidal gene. Plant Biotechnol., 17: 105-110. http://sciencelinks.jp/jeast/article/200017/000020001700A0566711.php

33. Sanjaya, V.V.S., V. Prasad, N. Kirthi, S.P. Maiya, H.S. Savithri and G.L. Sita, 2005. Development of cotton transgenics with antisense AV2 gene for resistance against cotton leaf curl virus (CLCuD) via Agrobacterium tumefaciens. Plant Cell Tiss. Organ Cult., 81: 55-63. DOI: 10.1007/s11240-0042777-7

34. Punja, Z.K., 2001. Genetic engineering of plants to enhance resistance to fungal pathogens-a review of progress and future prospects. Can. J. Plant Pathol., 23: 216-235. http://article.pubs.nrccnrc.gc.ca/RPAS/rpv?hm=HInit\&journal=tcjpp\&v olume $=23 \& \mathrm{afpf}=\mathrm{k01}-032$.pdf 
35. Punja, Z.K. and Y.Y. Zhang, 1993. Plant chitinases and their roles in resistance to fungal disease. $\mathrm{J}$. Nematol., 25: 526-540. http://www.pubmedcentral.nih.gov/articlerender.fc gi? artid=2619419

36. McFadden, H., R. DeFeyter, F. Murray, A. Grover, D. Llewellyn, E. Dennis and W.J. Peacock, 2000. Genetic Engineering Approaches to the Improvement of Cotton's Tolerance to Verticillium Wilt. In: Advances in Verticillium Research and Diseases Management, Tjamos, E.C., R.C. Rowe, J.B. Heale and D.R. Fravel (Eds.). APS Press, St Paul, MIN., pp: 187-191.

37. Emani. C., J.M. Garcia, E. Lopata-Finch, M.J. Pozo, P. Uribe, D.J. Kim and G. Sunilkumar, 2003. Enhanced fungal resistance in transgenic cotton expressing an endochitinase gene from Trichoderma virens. Plant Biotechol. J., 1: 321-336. http://www.ncbi.nlm.nih.gov/pubmed/17166131

38. Sunilkumar, G. and K.S. Rathore, 2001. Transgenic cotton: factors influencing Agrobacterium-mediated transformation and regeneration. Mol. Breed., 8: 37-52. DOI: 10.1023/A:1011906701925

39. Rajasekaran, K., J.W. Cary, T.J. Jacks, K. Stromberg and T.E. Cleveland, 2000. Inhibition of fungal growth in plants and in vitro by transgenic tobacco expressing a bacterial non-heme chloroperoxidase gene. Plant Cell Rep., 19: 333-338. http://cat.inist.fr/?aModele $=$ afficheN\&cpsidt $=1325$ 236

40. Chen, Z.Y., R.L. Brown, J.S. Russin, A.R. Lax and T.E. Cleveland, 1999. A corn trypsin inhibitor with antifungal activity inhibits Aspergillus flavus $\alpha-$ amylase. Phytopathalogy, 89: 902-907. http://cat.inist.fr/?aModele $=$ afficheN\&cpsidt $=1967177$

41. Murray, F., D. Llewellyn, H. McFadden, D. Last, E.S. Dennis and W.J. Peacock, 1999. Expression of the Talaromyces flavus glucose oxidase gene in cotton and tobacco reduces fungal infection, but is also phytotoxic. Mol. Breed., 5: 219-232. DOI: 10.1023/A:1009625801909

42. Shinshi, H., J.M. Neuhaus, J. Ryals and F. Meins Jr, 1990. Structure of a tobacco endochitinase gene: Evidence that different chitinase genes can arise by transposition of sequences encoding a cysteine-rich domain. Plant Mol. Biol., 14: 357-368. http://view.ncbi.nlm.nih.gov/pubmed/1966383
43. Lin, W., C.S. Anuratha, K. Datta, I. Potrykus, S. Muthukrishnan and S.K. Datta, 1995. Genetic engineering of rice for resistance to sheath blight. Biotechnology, 13: 686-691. DOI: 10.1038/nbt0795-686

44. Tabei, Y., S. Kitadem, Y. Nishizawa, N. Kikuchi, T. Kayano, T. Hibi and M. Akutsu, 1998. Transgenic cucumber plants harboring a rice chitinase gene exhibit enhanced resistance to gray mold (Botrytis cinerea). Plant Cell Rep., 17: 159-164. http://cat.inist.fr/?aModele $=$ afficheN\&cpsidt $=2098$ 093

45. Melchers, L.S., A. Groot, V.D. Knaap, A.S. Ponstein, M.B. Sela-Buurlage and J.E. Bol, 1994. A new class of tobacco chitinases homologous to bacterial exo-chitinases displays antifungal activity. Plant J., 5: 469-480.

http://www.ncbi.nlm.nih.gov/pubmed/8012401

46. Neuhaus, J.M., P. Ahl-Goy, U. Hinz, S. Flores and F. Meins Jr, 1991. High level expression of a tobacco chitinase gene in Nitotiana sylvestris susceptibility of transgenic plants to Cercospora nicotianae infection. Plant Mol. Biol., 16: 141-151. http://cat.inist.fr/?aModele $=$ afficheN\&cpsidt $=5602$ 852

47. Nielsen, K.K., J.D. Mikkelsen, K.M. Kragh and K. Bojsen, 1993. An acidic class I chitinase in sugar beet: Induction by Cercospora beticola, characterization and expression in transgenic tobacco plants. Mol. Plant Microbe Interact., 6: 495-506. http://www.ncbi.nlm.nih.gov/pubmed/8400378

48. Baranski, R., E. Klocke and T. Nothnagel, 2007. Enhancing resistance of transgenic carrot to fungal pathogens by the expression of Pseudomonas fluorescence microbial factor 2 (MF3) gene. Physiol. Mol. Plant Pathol., 71: 88-95. http://cat.inist.fr/?aModele $=$ afficheN\&cpsidt $=2020$ 0713

49. Adhikari, T.B., B. Balaji, J. Breeden and S.B. Goodwin, 2007. Resistance of wheat to Mycosphaerella graminicola involves early and late peaks of gene expression. Physiol. Mol. Plant Pathol., 71: 55-68. http://cat.inist.fr/?aModele $=$ afficheN\&cpsidt $=2020$ 0710 